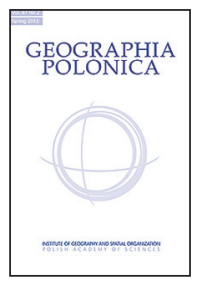 \\ INSTITUTE OF GEOGRAPHY AND SPATIAL ORGANIZATION \\ POLISH ACADEMY OF SCIENCES \\ www.igipz.pan.pl \\ www.geographiapolonica.pl
}

\title{
DELIMITATION OF PROBLEM AREAS IN POLAND
}

\section{Przemysław Śleszyński • Jerzy Bański • Marek Degórski • Tomasz Komornicki}

Institute of Geography and Spatial Organization

Polish Academy of Sciences

Twarda 51/55, 00-818 Warsaw: Poland

e-mails: psleszyn@twarda.pan.pl•jbanski@twarda.pan.pl•m.degor@twarda.pan.pl・t.komorn@twarda.pan.pl

\begin{abstract}
The study presents the delimitation of problem areas carried out at the Institute of Geography and Spatial Organization of PAS on behalf of the Ministry of Development of Poland (2015-2016), first and foremost to meet the practical needs of the development policy being pursued at state, regional and local government levels. The study was elaborated for the 2479 Polish communes (gminas) by reference to 21 indicators mainly concerned with the state of the natural environment and socio-economic conditions, as well as features of spatial and local development. The three categories of area ultimately identified were the natural, the social and the economic aspects, the combination of which yielded several main types of problem area. A last stage then entailed a division into regions, i.e. the designation and naming of particular geographical areas.
\end{abstract}

\section{Key words}

problem areas $\bullet$ delimitation $\bullet$ development policy $\bullet$ regional policy

\section{Introduction}

Problem areas or regions as places of socioeconomic under-development can be found in the core-periphery theory context, even from as early as the 19th century (Ratzel 1896). The theory in question holds that peripheral areas are places of stagnation or sluggish development that depend on the so-called core areas (large cities, zones of industrial development, etc.). In contrast, what was probably the first (or one of the first) detailed proposals for the classification of problem areas came along in the work of Hoover and Fisher (1949), in the context of 'regional pathology'. What were identified here were 'lagging or backward regions', 'new but underdeveloped regions' and 'stranded and chronically depressed areas'. 
The Polish literature itself boasts a quite long and rich tradition of work seeking to delimit problem areas. The first, more in-depth classifications and delimitations of problem areas are to be found in work from the 1980s diagnosing the state of the national economy and ongoing socioeconomic processes (i.a. Kukliński 1983; Kokotkiewicz 1985; Kassenberg \& Rolewicz 1986; Zagożdżon 1988). These works took in population issues, agriculture, asocial behaviours, health problems and environmental threats. In subsequent years, matters of this kind were in particular researched at the Institute of Geography and Spatial Organization of the PAS (IGSO PAS) (Gawryszewski \& Potrykowska 1988; Eberhardt 1989; Kulikowski 1992; Bański 1999, 2001, 2002, 2008; Węcławowicz et al. 2006; Mazur et al. 2015); at the Institute of Rural and Agricultural Development of the PAS (Rosner 1999, 2002), at the Institute of Soil Science and Plant Cultivation in Puławy (Jadczyszyn 2009) and at certain other academic centres (Dembowska 1994; Churski 2004, 2005). Not all the work adopted a Poland-wide approach, with quite a few studies dealing with delimitation at sub-regional level (Ciok 1991; Brodziński 2002; Ślusarz 2005; Musiał 2008; Smętkowski 2012; Czapiewski \& Janc 2013; Śleszyński 2014), within agglomerations (Węcławowicz 1991), or even in individual cities (Stępniak et al. 2009; Śleszyński 2010). Part of this growing interest had practical underpinnings, most especially in connection with the need to modify regional policy following accession to the EU, but also as a response to observed socioeconomic polarisation.

Within the Polish regional policy framework, the individualised nature of regional development found its reflection in concepts relating to units of the 'functional area' (obszar funkcjonalny; OF), 'area of strategic intervention' (obszar strategicznej interwencji; OSI) and 'problem area' (obszar problemowy; OP) types. Special development instruments were addressed to each of these, with the packages including financial incentives, investment policies selected appropriately and special investment streams. Areas of this kind have also been identified in the context of the still-binding National Spatial Development Concept 2030 (2011), as well as the National Strategy of Regional Development 2010-2020 (2014).

\section{Methodological concept and assumptions}

The means of delimiting problem areas presented here is one of the main outcomes of a project implemented at IGSO PAS in the years 2015-2016, at the behest of Poland's Ministry of Development. The title was: "The identification of areas of strategic state intervention, including problem areas", and what was proposed there was a division of areas necessitating strategic intervention into areas of growth and problem areas, and with a further differentiation in terms of territorial extent - into national, regional and local areas of growth.

The delimitation of problem areas is achieved by way of a standard statistical analysis, with a key matter being the assessment of the level of socioeconomic development in uniform units of territorial administration (at the local-authority level of the Polish commune/gmina). Reference is then made to appropriately-selected diagnostic indicators also representing potential instruments by which changes following interventions can be monitored. At the outset, seven indicators or measures were selected for each group of issues recognised as natural, social and economic. A division into these three categories was considered to represent the most adequate means of conveying the essence of the issues and problems potentially existing, as well as the possibility for these to be identified geographically. The indicators in question are those detailed as follows.

\section{Natural indicators}

1. green areas (forests and woodlands plus urban greenery, though excluding cemeteries) in $\mathrm{m}^{2}$ per inhabitant;

2. share of the area threatened by flooding or inundation (by reference to moist 
habitats on maps of potential vegetation after Matuszkiewicz et al. 1995);

3. the Climatic Water Balance Index (from IUNG - the Institute of Soil Science and Plant Cultivation in Puławy);

4 . indicator of areas of unfavourable landmanagement conditions (also from IUNG in Puławy);

5. indicator in the form of the product of the number of inhabitants and the area of land valuable from the natural point of view (also with weighting in line with the particular categories of protected area represented; Degórski 2015);

6. index of landscape fragmentation (after Śleszyński \& Solon 2017);

7. indicator reflecting the share of the populace served by wastewater treatment plants.

\section{Social indicators}

1. share of the population of post-productive age $(60 / 65+)$;

2. net migration index: balance between permanent stay registrations and deregistrations from a permanent address per 100 inhabitants;

3. share of the population aged 13 and over with higher education;

4. mean results obtained in primary-school tests;

5. share of population availing of social welfare in line with the criterion of income;

6. the highest turnout achieved at general elections;

7. synthetic indicator of temporal accessibility to centres offering services of different level (Śleszyński 2016).

\section{Economic indicators}

1. the GDP per capita (in relation to the average nationally);

2. number of businesses entities in high specialized services per 1000 inhabitants;

3. own incomes in commune (gmina) budgets per capita;

4. usable floor area of completed dwellings per capita;
5. numbers unemployed per 100 people of productive age;

6. potential multimodal commodity accessibility indicator (after Komornicki et al. 2015).

7. share of built-up and urbanised areas.

Such statistical data, most often collected in 2014, or else in the 2010-2014 period, are from Poland's Central Statistical Office (GUS), the State Electoral Commission, the Central Examination Commission, the Institute of Soil Science and Plant Cultivation in Puławy, and IGSO PAS. All measures were standardised, before these standardised values of indicators were assigned ranks between 1 and 10, in line with a division into 10 equally-sized groups of analysed territorial units. The first $10 \%$ of the components (communes) with the lowest values for an indicator obtained rank 1 , the next 10\% rank 2 and so on. These data were then summed up for each commune in respect of the 7 indicators in each group, so that a synthetic index value was obtained (Fig. 1). The last stage entailed the determination of threshold values below which a given territorial unit was incorporated into one problem area or another. It was decided that the arithmetic mean should be applied, as increased by the standard deviation.

Statistical analysis revealed that certain territorial units are characterised by more than one group of problem areas. This led to a final proposal involving 7 types of problem area or areas in which various problems are concentrated, i.e.:

- social,

- economic,

- natural,

- social and economic,

- economic and natural,

- social, economic and natural.

\section{Results}

Areas facing problems of a natural character were identified in 424 of the Polish communes (i.e. $17 \%$ of the total, covering $16 \%$ of Poland's area and accounting for some $31 \%$ of its population). The problem areas of this kind are 

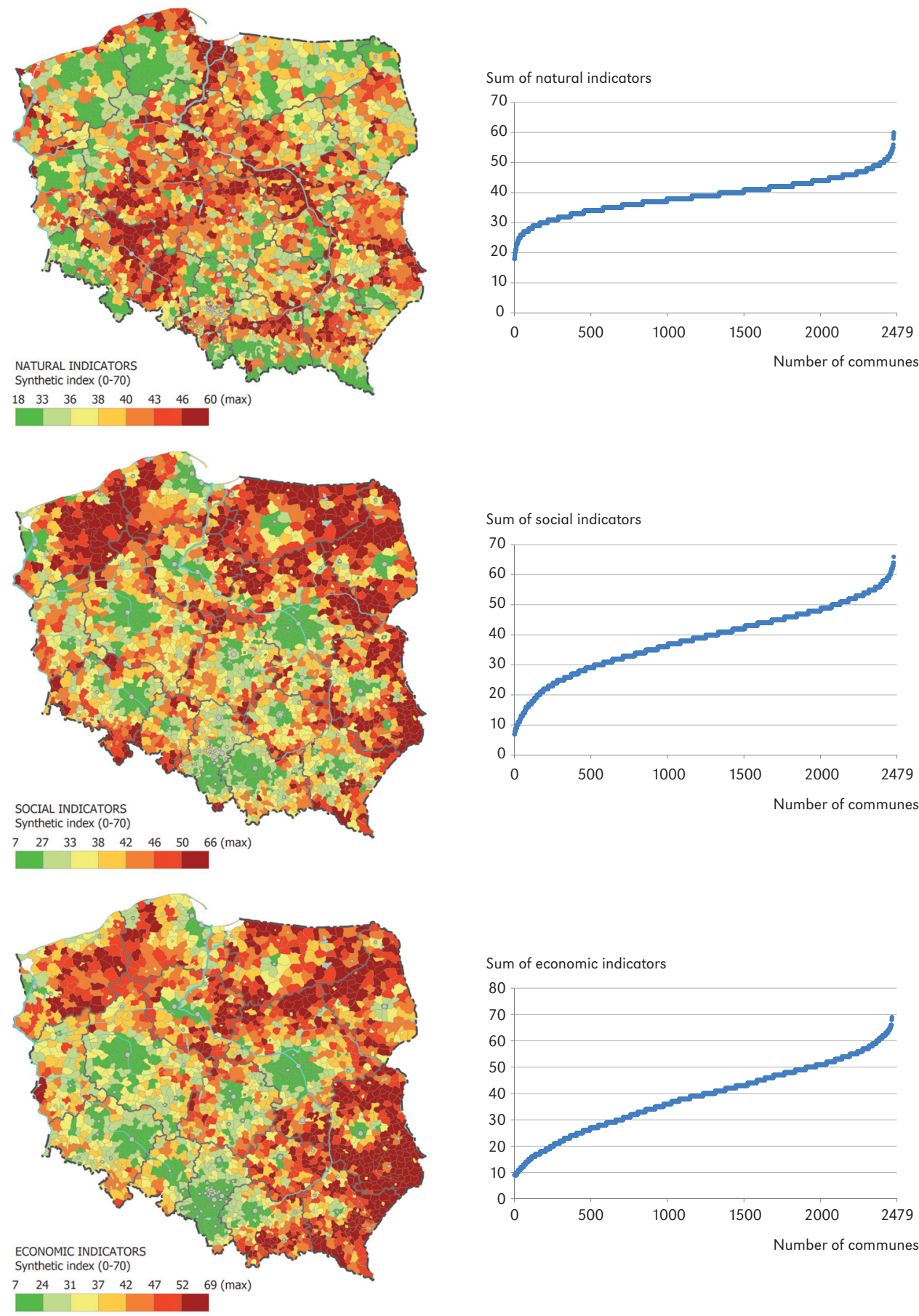

Figure 1. Spatial differences in values for the intensity of occurrence of problem features, as well as the breakdown for values of totals of delimitation indices applying to natural, social and economic problem areas (as based on the standardisation and summation of features) 
concentrated spatially in the Mazowieckie, Wielkopolskie and Lubelskie voivodeships, with these three accounting for $40 \%$ of all the communes characterised in this way. The largest natural problem areas are present in the lower and middle Vistula Valley, as well as along the upper River Odra. In each case there is a considerable risk of flooding being faced. Other key environmental problems arise from coastal erosion, shortages of water, soil erosion and the fragmentation of forest complexes.

Social problem areas in turn spread over more than $16 \%$ of all Poland's communes, with those involved covering $21 \%$ of the country's area, though inhabited by not much over $6 \%$ of its population. The problems in question appear first and foremost in rural or weaklyurbanised areas. The largest contiguous areas of occurrence of problem areas in this category are in Central Pomerania, as well as the north-east and east of Poland. These problems first and foremost reflect migratory outflow and accelerated population ageing.

Economic problem areas are in turn present over 428 communes (which account for $20 \%$ of Poland's area and $7 \%$ of its population). The largest numbers of units of this type are present in Lubelskie (Lublin) voivodship, which includes almost $1 / 3$ of all the communes identified), as followed by Mazowieckie, Podkarpackie and Podlaskie. The spatial distribution obtained reveals that the most important factors deciding about economic problems include a (monofunctional) agricultural nature of a local economy, a low level of business activity among inhabitants and a level of unemployment that is high in comparison with other regions.

The delimitation of problem areas confirmed facts known from the subject literature, including the phenomenon whereby problem phenomena are first and foremost identified in eastern Poland and Central Pomerania (Bański 2001; Węcławowicz et al. 2006; Gorzelak 2007; Korcelli et al. 2010; Czyż 2012; Stanny 2013). Analyses also indicate that the largest group is formed by areas in which natural problems are concentrated
(361 communes), followed by economic (194), social and economic (188), and social (182). There is thus a key interdependence between the social and economic areas, hence the recognition that further delimitation should combine together these two types.

The ultimate delimitation of precisely-defined geographical regions was based on the assumption that the procedure involved would be deductive, and in line with the premises that:

1. a dual procedure based on the distinguishing of socioeconomic and natural areas would be followed, given the high level of concordance in the case of these areas;

2. the areas identified ought to have a 'critical mass', in the sense that they should comprise at least a certain minimal number of communes (a figure of 10 gminas was decided upon, with the exception of the Ponidzki problem area);

3. the areas distinguished should be as contiguous as possible.

The result of the delimitation work engaged in is the proposal presented on the appended map. The twenty-four areas distinguished were 14 of a socioeconomic nature and 10 that were natural in character. It was decided that some of these might be further aggregated into groups of area, given proximity and a context of broader geographical and/or historic-cultural structures.

Obviously, the areas identified are approximate in nature (though capable of being defined in more detail by reference to the communes - making them up). What are nevertheless made quite clear are general regularities as regards the territorial and developmental handicapping of large parts of Poland, which are simultaneously to be viewed as points of reference where targeted regional policy is concerned.

\section{Conclusions}

The delimitation of problem areas detailed here mostly served to confirm territorial divisions already known from the subject literature. However, from a macrospatial point 
of view it is clear that problem areas concentrate, not merely in 'the east' of Poland as broadly construed, but also in 'the north' of Poland as perceived in an analogous way. At the same time, the Eastern Poland that is the recipient of a special policy is shown not to have been delimited in an optimal way. For this is by no means a uniform area in the context of Poland's division into regions. When it comes to the intensity of social and economic problems that have arisen, it would be more appropriate to refer to Northern Poland as a wider problem area. In this region lie those problem areas that fall beyond a triangle characterised by the highest level of socioeconomic activity, as well as density of population (whose apex is located in the TriCity, and whose base runs along the corridor of the A4 motorway).

The work reveals that a very mosaic-like configuration of variables describing levels of development and quality of life is present in many regions of the country. Units that

\section{References}

BAŃSKI J., 1999. Obszary problemowe w rolnictwie Polski. Prace Geograficzne, 172, Warszawa: Instytut Geografii i Przestrzennego Zagospodarowania PAN.

BAŃSKI J., 2001. Problem areas in Polish agriculture. Geographia Polonica, vol. 74, no. 1, pp. 47-63.

BAŃSKI J., 2002. Typy ludnościowych obszarów problemowych. Studia Obszarów Wiejskich, 2, Warszawa: Polskie Towarzystwo Geograficzne, Instytut Geografii i Przestrzennego Zagospodarowania PAN, pp. 41-52.

BAŃSKI J., 2008. Wiejskie obszary problemów demograficznych [in:] Wybrane zagadnienia systemów informacji przestrzennej i obszarów problemowych rolnictwa w Polsce. Program Wieloletni 2005-2010, Studia i Raporty IUNG-PIB, no. 12, Puławy: Instytut Uprawy Nawożenia i Gleboznawstwa PIB, pp. 93-102.

BRODZIŃSKI Z., 2002. Obszary problemowe w rolnictwie na przykładzie województwa warmińsko-mazurskiego. Fragmenta Agronomica, vol. 19, no. 1, pp. 201-212. emerge as well-developed border directly on to areas very much lagging behind and beset by problems. This is evidence of insufficient diffusion of development factors and their excessive patchiness, and it offers indications for strategic intervention that should seek to remove or limit barriers to the diffusion process of this kind. Among other things, efforts should be made to favour the deglomeration of job opportunities and public services in metropolitan areas, support for cooperation between units of local-government administration with actual or potential functional areas, the improvement of conditions as regards commutes to work, and job creation in towns and cities that are in decline, most especially in the context of Poland's ongoing process of depopulation.

Editors' note:

Unless otherwise stated, the sources of tables and figures are the authors', on the basis of their own research.

Churski P., 2004. Struktura społeczno-gospodarcza obszarów problemowych w Unii Europejskiej i w Polsce w świetle unijnej polityki regionalnej. Przegląd Geograficzny, vol. 76, no. 2, pp. 189-208.

CHURSKI P., 2005. Problem areas in Poland in terms of the objectives of the European Union's regional policy. European Planning Studies, vol. 13, no. 1, pp. 45-72.

Ciok S., 1991. Sudety. Obszar problemowy. Studia Geograficzne, 51, Acta Universitatis Wratislaviensis, Wrocław: Wydawnictwo Uniwersytetu Wrocławskiego.

CzYż T., 2012. Poziom rozwoju społeczno-gospodarczego Polski w ujęciu subregionalnym. Przeglad Geograficzny, vol. 84, no. 2, pp. 219-236.

CZAPIEWSKI K., Janc K., 2013. Edukacja jako czynnik rozwoju Mazowsza. Trendy Rozwojowe Mazowsza, vol. 11, Warszawa: Mazowieckie Biuro Planowania Regionalnego.

Degórski M., 2015. Polityka krajobrazowa Polski: wyzwania i szanse. Problemy Ekologii Krajobrazu, vol. 40, pp. 13-26. 
Dembowska Z., 1994. Obszary problemowe w Polsce. Warszawa: Instytut Gospodarki Przestrzennej i Komunalnej.

EBERHARDT P., 1989. Regiony wyludniajace się w Polsce. Prace Geograficzne, 148, Warszawa: Instytut Geografii i Przestrzennego Zagospodarowania PAN.

Gawryszewski A., Potrykowska A., 1988. Rural depopulation areas in Poland. Geographia Polonica, vol. 54, pp. 81-99.

GORZELAK G. (ed.), 2007. Polska regionalna i lokalna w świetle badań EUROREG. Warszawa: Wydawnictwo Naukowe Scholar.

HoOver E.M., FISHER J.L. 1949. Research in regional economic growth [in:] Problems in the study of economic growth, National Bureau of Economic Research, Universities-National Bureau, pp. 173-250.

JADCZYSZYN J., 2009. Regionalne zróżnicowanie obszarów problemowych rolnictwa (OPR) w Polsce. Instrukcja upowszechnieniowa nr 163. Puławy: Instytut Uprawy Nawożenia i Gleboznawstwa PIB.

Kassenberg A., Rolewicz C., 1984. Obszary ekologicznego zagrożenia (wstępna diagnoza przestrzenna - 1980 r.). Studia KPZK PAN, vol. 85, pp. 150-155, Warszawa: Państwowe Wydawnictwo Naukowe.

KokOTKIEWICZ I., 1985. Obszary problemowe w Polsce. Interpretacja z punktu widzenia zagrożeń społecznych [in:] A. Kukliński (ed.), Gospodarka przestrzenna Polski wczoraj, dziś i jutro, 2, Warszawa: PAX, pp. 84-96.

KOMORNICKI T., ŚLESZYŃSKI P., 2009. Typologia obszarów wiejskich pod względem powiqzań funkcjonalnych i relacji miasto-wieś [in:] J. Bański (ed.), Analiza zróżnicowania i perspektyw rozwoju obszarów wiejskich w Polsce do 2015 roku, Studia Obszarów Wiejskich, 16, Warszawa: Polskie Towarzystwo Geograficzne, Instytut Geografii i Przestrzennego Zagospodarowania PAN, pp. 9-38.

Komornicki T., Rosik P., Śleszrński P., Stępniak M., 2015. Oszacowanie wartości wskaźnika dostępności czasowej na potrzeby dokumentów strategicznych, których postępy sq monitorowane w ramach bazy STRATEG (izochrona drogowa 60 i 90 minut). Warszawa: Instytut Geografii i Przestrzennego Zagospodarowania PAN.

Korcelli P., Degórski M., Drzazga D., KomornicKI T., Markowski T., Szlachta J., WęCŁaWOWICZ G., ZALESKI J., ZAuCHA J., 2010. Ekspercki projekt koncepcji przestrzennego zagospodarowania kraju do roku 2033. Studia KPZK PAN, vol. 78, Warszawa: Komitet Przestrzennego Zagospodarowania Kraju PAN.

KUKLIŃSKI A. (red.), 1983. Diagnoza stanu gospodarki przestrzennej Polski. Wstępne wyniki badań. Biuletyn KPZK PAN, vol. 123, Warszawa: Państwowe Wydawnictwo Naukowe.

KULIKOWSKI R., 1992. Obszary problemowe rolnictwa w Polsce. Biuletyn KPZK PAN, vol. 158, pp. 23-40.

Matuszkiewicz W., Faliński J.B., Kostrowicki A.S., Matuszkiewicz J.M., Olaczek R., Wojterski T., 1995. Potencjalna roślinność naturalna Polski. Mapa przeglądowa 1:300 000. Arkusze 1-12. Warszawa: Instytut Geografii i Przestrzennego Zagospodarowania PAN.

Mazur M., Bański J., CZAPIEWSKI K., Śleszyński P., 2015. Wiejskie obszary funkcjonalne - próba metodyczna wyznaczenia ich obszarów i granic. Studia Obszarów Wiejskich, 37, Warszawa: Polskie Towarzystwo Geograficzne, Instytut Geografii i Przestrzennego Zagospodarowania PAN, pp. 7-36.

Musiat W., 2008. Obszary problemowe rolnictwa $w$ terenach górzystych. Studia i Raporty IUNG-PIB, vol. 12, pp. 81-92.

National Strategy of Regional Development 2010-2020, 2014. Warsaw: Ministry of Regional Development.

National Spatial Development Concept 2030, 2011. Warsaw: Ministry of Regional Development.

Ratzel F., 1896. Die Gesetze des raumlichen Wachstums der Staaten. Petermanns Mitteilungen, vol. 45, no. 5, pp. 97-107.

Rosner A.(ed.), 1999. Typologia wiejskich obszarów problemowych. Warszawa: Instytut Rozwoju Wsi i Rolnictwa PAN.

Rosner A. (ed.), 2002. Wiejskie obszary kumulacji barier rozwojowych. Warszawa: Instytut Rozwoju Wsi i Rolnictwa PAN.

ŚLESZYŃSKI P., 2010. Struktura przestrzeni i delimitacja obszarów społecznych w Warszawie. Dane NSP 2002. Polityka Społeczna, vol. 37, no. 1, pp. 14-18.

ŚlesZYŃSKI P., 2014. Przemiany społeczno-demograficzne województwa mazowieckiego w latach 1990-2030. Trendy Rozwojowe Mazowsza, vol. 15, Warszawa: Mazowieckie Biuro Planowania Regionalnego. 
ŚLESZYŃSKI P., 2016. A synthetic index of the spatiotemporal accessibility of communes in Poland. Geographia Polonica, vol. 89, no. 4, pp. 567-574.

ŚLESZYŃSKI P., SOLON J., 2017. Map of landscape diversity of Poland. Geographia Polonica, vol. 90, no. 3 (forthcoming).

ŚlUSARZ G., 2005. Studium spoteczno-ekonomicznych uwarunkowań rozwoju obszarów wiejskich w świetle zagrożenia marginalizacja - na przykładzie województwa podkarpackiego. Prace Naukowe Wydziału Ekonomii Uniwersytetu Rzeszowskiego. Monografie i Opracowania, vol. 1(379).

SMĘTKOWSKI M., 2012. Wschodnie obszary problemowe i ich trajektorie rozwojowe na przykładzie Polski i Niemiec. Studia Regionalne i Lokalne, no. 4(50), pp. 29-53.

Stanny M., 2013. Przestrzenne zróżnicowanie rozwoju obszarów wiejskich w Polsce. Warszawa Warszawa: Instytut Rozwoju Wsi i Rolnictwa PAN.
Stępniak M., Węctawowicz G., Górczyńska M., BIERZYŃSKI B., 2009. Warszawa w świetle Narodowego Spisu Powszechnego 2002. Atlas Warszawy, vol. 11, Warszawa: Instytut Geografii i Przestrzennego Zagospodarowania PAN.

WęCŁAWowicz G., 1991. Zróżnicowania społeczno-przestrzenne w aglomeracji warszawskiej (1978 i 1988). Zeszyty IGiPZ PAN, vol. 2, Warszawa: Instytut Geografii i Przestrzennego Zagospodarowania PAN.

Węctawowicz G., Bański J., Degórski M., KomorNICKI T., KorCellI P., ŚleszYŃSKI P., 2006. Przestrzenne zagospodarowanie Polski na poczatku XXI wieku. Monografie, vol. 6, Warszawa: Instytut Geografii i Przestrzennego Zagospodarowania PAN.

ZAGOŻDŻON A., 1988. Kilka uwag o obszarach problemowych. Biuletyn KPZK PAN, vol. 138, pp. 137-147. 


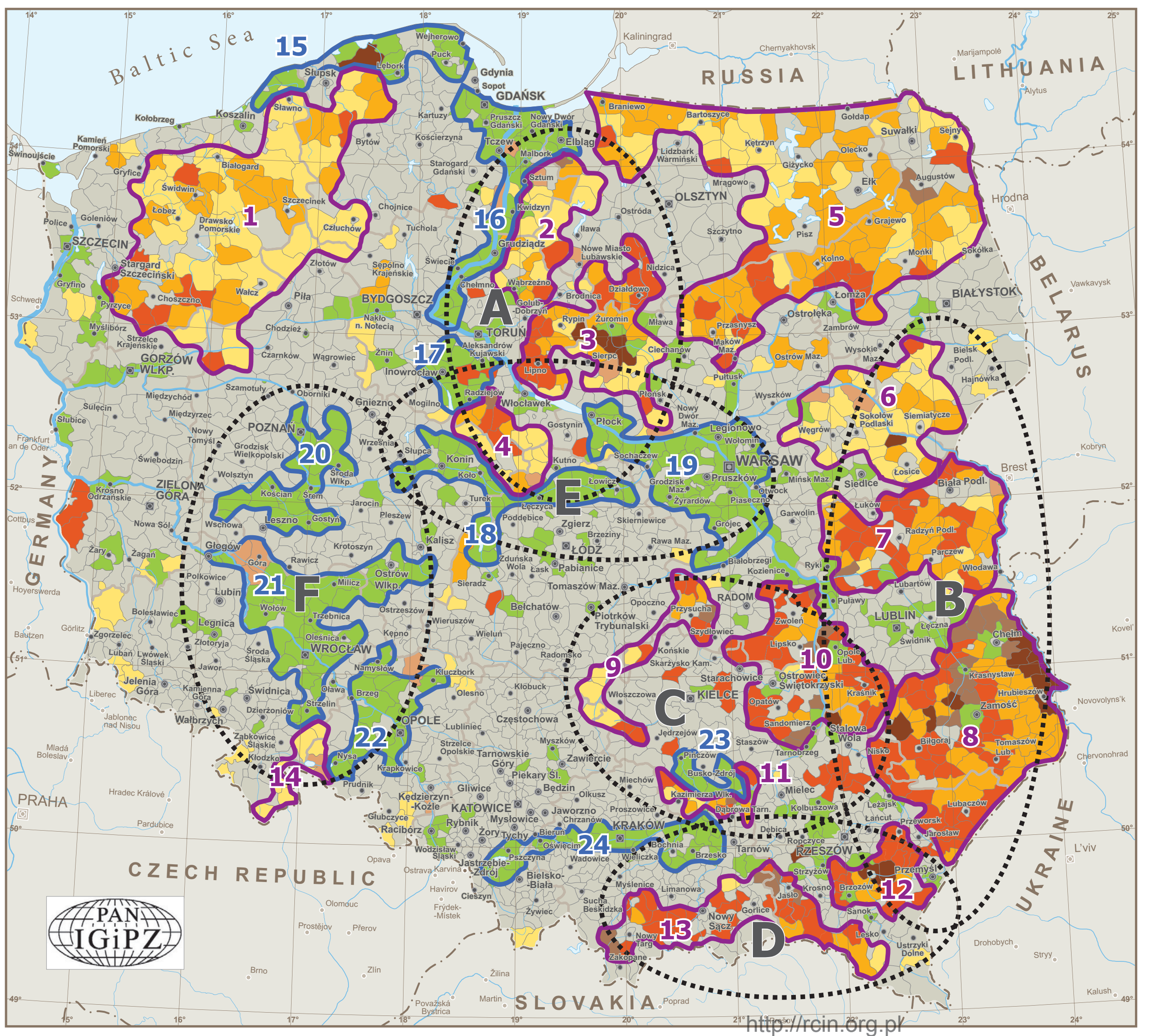

DELIMITATION OF PROBLEM AREAS IN POLAND

Przemysław Śleszyński, Jerzy Bański, Marek Degórski, Tomasz Komornicki

Scale 1:3,000,000 $\stackrel{0}{0 \quad 25} \quad 50 \quad 75 \quad 100 \mathrm{~km}$

Types of problem areas

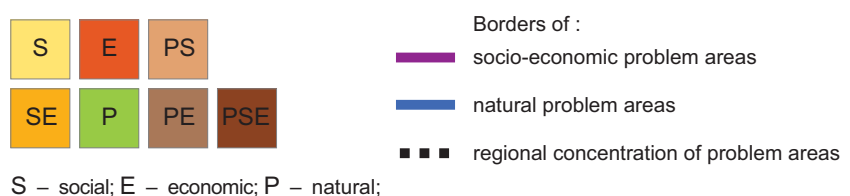

Capital categories:
Poland

回 Poland
【 voivodeship

- poviat

PROBLEM AREAS IN POLAND (2014)

\begin{tabular}{|c|c|c|c|c|c|}
\hline No. & $\begin{array}{c}\text { Area } \\
\text { group }\end{array}$ & $\begin{array}{l}\text { Name } \\
\text { (in Polish) }\end{array}$ & $\begin{array}{l}\text { Number } \\
\text { of communes }\end{array}$ & $\begin{array}{l}\text { Area } \\
\left(\mathrm{km}^{2}\right)\end{array}$ & $\begin{array}{c}\text { Number } \\
\text { of population } \\
\text { (thous.) }\end{array}$ \\
\hline \multicolumn{6}{|c|}{ Socio-economic } \\
\hline 1 & & Pomorski & & $\begin{array}{lll}17,779 \\
\end{array}$ & 695 \\
\hline 2 & & Powiślański & 28 & 3,799 & 236 \\
\hline $\begin{array}{l}3 \\
4 \\
3\end{array}$ & A & $\begin{array}{l}\text { Brodnicko-Mławski } \\
\text { Kuliawski }\end{array}$ & 54 & $\begin{array}{l}6,570 \\
2321 \\
241\end{array}$ & 398 \\
\hline & & $\begin{array}{l}\text { Kulawski } \\
\text { Pónocno-Wschodni }\end{array}$ & $\begin{array}{l}22 \\
125\end{array}$ & $\begin{array}{r}2,344 \\
24,092\end{array}$ & $\begin{array}{c}1.134 \\
1.091\end{array}$ \\
\hline${ }^{0}$ & B & Podlaski & 55 & 7,051 & $\begin{array}{l}1,0916 \\
316\end{array}$ \\
\hline & B & Polesko-Łukowski & 58 & 7,703 & 438 \\
\hline 8 & B & Lubelski & 105 & 13,244 & 829 \\
\hline 10 & c & $\begin{array}{l}\text { Przysusko-Plilicki } \\
\text { Sandomierck Swiotkrzyi }\end{array}$ & $\begin{array}{l}21 \\
68\end{array}$ & $\begin{array}{l}2,878 \\
7537\end{array}$ & 118 \\
\hline 11 & $c$ & 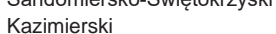 & & 1.229 & $\begin{array}{l}664 \\
104\end{array}$ \\
\hline 12 & D & Strzyzowsko-Dynowski & 27 & 2,667 & $\begin{array}{l}104 \\
228\end{array}$ \\
\hline 13 & & Karpacki & 62 & 6,192 & 783 \\
\hline 14 & & Kłodzki & 10 & 1,678 & 90 \\
\hline \multirow{2}{*}{\multicolumn{6}{|c|}{6,124}} \\
\hline & & & & & \\
\hline 15 & & Nadbałtycki & 20 & 3,218 & \\
\hline 16 & & Dolnej Wisty & 38 & & 1,188 \\
\hline $\begin{array}{l}17 \\
18\end{array}$ & $\mathrm{E}$ & Kujawski & 13 & 作, 1,508 & $\begin{array}{l}177 \\
356\end{array}$ \\
\hline 19 & & Warszawsko-Kampinoski & 72 & & $\begin{array}{l}356 \\
3.128\end{array}$ \\
\hline 20 & $\mathrm{~F}$ & Leszczýnski & 23 & 3,350 & $\begin{array}{l}3,128 \\
967\end{array}$ \\
\hline 21 & $\mathrm{~F}$ & Wroctawsko-Kaliski & 40 & 6,794 & 1,217 \\
\hline 22 & $\mathrm{~F}$ & Opolski & 22 & 3,259 & 385 \\
\hline $\begin{array}{l}23 \\
24\end{array}$ & & $\begin{array}{l}\text { Ponidzki } \\
\text { Podbeskidzki }\end{array}$ & 39 & $\begin{array}{r}906 \\
3,163\end{array}$ & $\begin{array}{r}58 \\
1,437\end{array}$ \\
\hline \multicolumn{3}{|c|}{ Total } & 306 & 36,296 & 9,229 \\
\hline
\end{tabular}

"Area group (in Polish): A- Pomorsko-Chelmiríska; B - Podlasko-Lubelska; C - Pothocnomalo

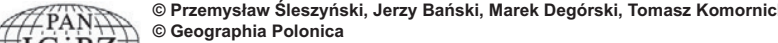

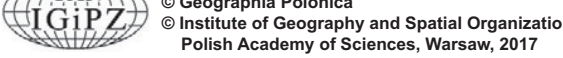

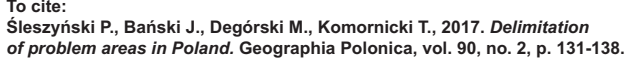

